\title{
Following the chromosome through history
}

\section{Soraya de Chadarevian: Heredity under the microscope. Chromosomes and the study of the human genome. Chicago: The University of Chicago Press, 2020, 272 pp, \$37.50 PB}

\section{Hans-Jörg Rheinberger ${ }^{1}$}

Accepted: 2 March 2021 / Published online: 21 March 2021

(c) The Author(s) 2021

This book teaches a lesson to all those who think that the history of heredity in the twentieth century has received so much attention from historians of the life sciences that another book-length account could not add a significantly new facet to the picture. Histories of classical genetics abound: they usually end where the history of molecular biology begins. Histories of molecular biology also abound: they usually follow the master narrative of a new biology that simply superseded classical genetics. Histories of research into human heredity have generally focused on the lure of eugenics, before as well as after World War II. Soraya de Chadarevian has managed to escape all three of these biases, without neglecting the grain of truth that inheres in each of them. She tells the history of-human-chromosome research in the second half of the twentieth century, showing that it developed alongside the rise of molecular genetics in an era when the focus was put on viruses and bacteria, and foregrounding the cold-war medical, epidemiological and environmental concerns that drove this history.

The book is by no means a disciplinary history of cytogenetics aimed at complementing, as it were, the history of molecular, developmental, and physiological genetics. Rather, the narrative aims at following an object, the chromosome, on its way through society, tracing the shapes it assumed on this itinerary, and high-lighting the power it gained through its visualizations.

The text is organized into five chapters that form a loose chronology. Chapter one places the renewed interest in human cytogenetic research in the first decade after World War II in the context of the atomic age, with its concerns about the effects of radiation resulting from both the military and civil uses of atomic energy that so profoundly marked the epoch. The fear of a global effect on human hereditary traits due to radiation damage was pervasive, with radiation-induced cancer being a particularly prominent concern. Research efforts aimed at limiting the associated risks

Hans-Jörg Rheinberger

rheinbg@mpiwg-berlin.mpg.de

1 Max Planck Institute for the History of Science, Berlin, Germany 
appeared as a necessary corollary to the massive worldwide expansion of nuclear technology. It is in this context that a new consensus about the number of human chromosomes was achieved, reducing the number of its full complement from 48 to 46. This chapter also shows how the new consensus critically depended on the development of a number of improved and standardized preparation procedures without which this agreement would have been impossible.

Chapter two is entitled "Chromosomes and the Clinic." It describes the emergence of what came to be termed "chromosome diseases," that is, the clinical syndromes that could be related to the identification of chromosomal anomalies, of which supernumerary chromosomes-such as in trisomy 21 , the syndrome named after John Langdon Down, a British physician of the nineteenth century-were among the most prominent. The hopes of preventing these chromosomal anomalies by prenatal diagnosis were as prominent as the ethical concerns they raised. De Chadarevian closely follows the different research trajectories that these contested dynamics generated both in France and in the United Kingdom.

Chapter three is devoted to the X and Y "sex" chromosomes, the diploid chromosome pair XX associated with the female, the XY pair with the male phenotype. After human chromosome counts had been rendered reliable, it soon turned out that conditions with supernumerary or missing X or Y chromosomes were among the most frequent "chromosome diseases." The syndrome named after the American physician Klinefelter and identified as a clinical syndrome in the early 1940s soon became ascribed to the karyotype XXY, and the Turner syndrome reliably described for the first time in the late 1930s, was now identified as monosomy X. XYY males became associated with aggressive behavior, crime, and mental underperformance. Not only did these sex chromosome abnormalities make it into the headlines of the popular press, but they also initiated large surveys of newborns in maternity clinics, as well as inmates in prisons and mental hospitals. These varieties of combinations of the 'sex' chromosomes also found their way into American courtrooms and, not insignificantly, into the arena of sports, with high-profile events such as the Olympic Games using chromosomal karyotyping to detect gender cheating among sportswomen. This chapter is particularly telling in that it shows how a scientific object converted and stabilized as a test can serve widely different interest groups, and also how it can change its meaning and importance precisely due to its vagaries. Here, the strength of the narrative strategy followed by the book-a history of research objects rather than of disciplines-becomes particularly palpable.

Chapter four looks into the efforts of the two decades between 1960 and 1980 to "scale up" chromosome research. Scaling up is analyzed across two axes. The first is connected with the growing efforts to automate karyotyping, a necessary prerequisite for developing medical, epidemiological and anthropological surveys related to the distribution of karyotypes, their evolutionary history, and the possible damage inflicted upon them by global environmental toxins. The second part of the chapter reports on the ensuing patient and population studies in which karyotyping played a major role.

In the final chapter, de Chadarevian takes up the challenge of showing that human cytogenetics based on conventional microscopy cannot simply be looked at as an outdated effort of the medical establishment, doomed to be superseded and cast into 
oblivion by the molecular DNA technologies resulting from the rise of molecular biology and its domination by ever more efficient sequencing technologies from the 1980s onwards. Rather it should be looked at as preparing the ground for the transition of molecular genetics to the realm of higher organisms, including humans, with the advent of new gene technologies. The latter paved the way for the Human Genome Project that was started in the late 1980s. However, this project could and had to build on the know-how of data management and statistics already put into place by its forerunners. With the newest wave of fluorescent visualization technologies, cytogenetics and their prime objects, the chromosomes, are once again back in the picture, this time no longer as dead material immobilized on microscopic slides, but made visible as an intricate, living cellular process.

In conclusion, Heredity Under the Microscope is an appropriate title for de Chadarevian's book in a number of different respects. First, it conveys the message that analytic technologies such as the ones favored and promoted by molecular biology never completely replaced the microscopic imaging tradition built up by and inherited from nineteenth-century cytology. Second, it can be read as pointing to the historical fact that research into hereditarian phenomena was never an one-dimensional enterprise and therefore should be related in all its different facets. And third, it reminds us of the microscopic gaze of a historian of science patiently sifting through the details of archival material and bringing to light the work of many a researcher who has not even made it into today's Wikipedia pages. Soraya de Chadarevian has written an homage to them all.

Funding Open Access funding enabled and organized by Projekt DEAL.

Open Access This article is licensed under a Creative Commons Attribution 4.0 International License, which permits use, sharing, adaptation, distribution and reproduction in any medium or format, as long as you give appropriate credit to the original author(s) and the source, provide a link to the Creative Commons licence, and indicate if changes were made. The images or other third party material in this article are included in the article's Creative Commons licence, unless indicated otherwise in a credit line to the material. If material is not included in the article's Creative Commons licence and your intended use is not permitted by statutory regulation or exceeds the permitted use, you will need to obtain permission directly from the copyright holder. To view a copy of this licence, visit http://creativecommons.org/licen ses/by/4.0/.

Publisher's Note Springer Nature remains neutral with regard to jurisdictional claims in published maps and institutional affiliations. 